\title{
Comments on "The Cenozoic fold-and-thrust belt of Eastern Sardinia: Evidences from the integration of field data with numerically balanced geological cross section" by Arragoni et al., 2016
}

\author{
F. Berra ${ }^{1}$, A. Lanfranchi ${ }^{2}$, F. Jadoul ${ }^{1}$ \\ ${ }^{1}$ Università degli Studi di Milano, Dipartimento di Scienze della Terra “A. Desio”, Milano, Italy \\ 2 Oolithica Geoscience LTD, Cheltenham, UK \\ Corresponding author: Fabrizio Berra (abrizio.berra@unimi.it)
}

\section{Key Points:}

- The paper published by Arragoni et al. 2016 suggests the existence of a Cenozoic foldand-thrust belt in Eastern Sardinia

- Field evidence indicates that the suggested tectonic contacts are stratigraphic boundaries

- There is no Cenozoic fold-and-thrust belt in Eastern Sardinia

\begin{abstract}
Arragoni et al. (2016) suggest in their paper published on Tectonics that the carbonate succession of Eastern Sardinia represents a Cenozoic fold-and-thrust belt, related to the Alpine orogenesis. According to these Authors, this supposed fold-and-thrust belt represents the southward prosecution of the Alpine Corsica collisional chain and the missing link between the Alpine Chain and the Calabria-Peloritani domain. Field evidence and the published literature document instead that all the surfaces that Arragoni et al. interpret as thrust are actually stratigraphic contacts. The balanced geological section of Arragoni represents thus a geometric exercise missing the basic data needed to nurse the proposed model and it does not reflect the geology of eastern Sardinia. The data provided by Arragoni et al. (2016) do not support the presence of an Alpine thrust and fold belt in eastern Sardinia and this paper may suggest to the geological community a misleading interpretation of the geodynamic evolution of the Alpine and Mediterranean area.
\end{abstract}

\section{Introduction}

A radically new geodynamic model for the Cenozoic evolution of the eastern Sardinia passive margin has been recently proposed by Arragoni et al (2016). These authors suggest the existence of an Alpine thrust and fold belt (involving sedimentary cover and basement) in an area where direct evidence of the Alpine Orogenic event has never been reported up to now. If correct, this 
interpretation has major implications on the regional evolution of the Alpine and TyrrhenianMediterranean area, with the inclusion of eastern Sardinia in the Alpine fold and thrust belt. We will provide evidence, using the available published data and field observations, of the stratigraphic nature of the contacts interpreted (with what, we think, is an insufficient amount of data) as tectonic surfaces by Arragoni et al. (2016). Consequently, this contribution is intended to demonstrate the absence of any Alpine fold and thrust belt in Eastern Sardinia.

\section{Geological framework}

During the Cenozoic, Sardinia and Corsica formed part of the West Tethys northern passive margin which also included the Pyrenean region to west and Brianconnaise domain to the east. Both of these regions recorded a compressional tectonic events during the Palaeocene to Eocene (e.g., Oggiano et al., 2009, and references therein). During Oligocene and Miocene the situation changed, with an extensional event associated with volcanic activity (Oligocene-Aquitanian; Casula et al; 2001). Sardinia was interested also by Oligo-Miocene strike slip tectonism associated with the opening of the Liguro-Provençal Basin during the Oligo-Miocene, when the CorseSardinian microplate rotated toward its present-day position (Alvarez, 1972).

The rotation resulted in a series of strike-slip faults controlling the present-day distribution of Mesozoic carbonate outcrops in eastern Sardinia (Carmignani et al., 1995; Pasci, 1997; Pasci et al., 1998; Dieni et al., 2008; Oggiano et al., 2009). This Mesozoic succession consists of a thick Jurassic-Cretaceous carbonate succession (Dieni \& Massari, 1985; Jadoul et al., 2009; 2010; Lanfranchi et al. 2011) that records the depositional history of the northern margin of the Penninic Ocean, unconformably covering the Variscan Basement. Structural studies on Eastern Sardinia identify an Oligo-Miocene strike-slip tectonic phase affecting the Mesozoic carbonates, locally with transpressional or transtentional component (Carmignani et al., 1995; Pasci, 1997; Pasci et al., 1998; Oggiano et al., 2009). Biostratigraphic data from syn-tectonic deposits (Cucurru-e-Flores Conglomerate, Lutetian) identified a compressional phase (related to wrench tectonics affecting the Variscan basement and the pre-Oligocene sedimentary cover with development of positive flower structures), possibly recording a distal influence of both Alpine and Pyrenean orogenic belts, followed by a transtensive phase, coeval with the rotation (Dieni et al., 2008). 


\section{Proposed model of Arragoni et al. (2016)}

The model proposed by Arragoni et al. (2016) includes a "meso-Alpine" compressional tectonic phase of Eocene-Oligocene age documented, according to these authors, by regional thrust contacts within the Mesozoic carbonate succession of the Orosei Gulf coastal massif, and the Supramonte area (their Fig. 9). This tectonic phase is considered responsible for a thrust and fold belts, with displacements of several km. A "statistical analysis" of bedding attitudes is the main supporting evidence of Arragoni et al. (2016) model, together with a figure of interpreted outcrops at macroscopic scale (their Fig. 6). The authors identify a number of bed-attitude domains, which identify a set of km-wide syncline and anticline structures (their Fig. 5). The supposed fold and thrust belt of eastern Sardinia is shown in ENE-WSW balanced geological cross-section (their Fig. 9) accounting for the recorded variations of bedding attitude. The balanced cross-section relies upon a series of flat-over-flat thrusts invariantly placed at the base of the Upper Tithonian Berriasian Mt. Bardia Formation, which is depicted as a km-scale tectonic contact all along the coastal massif between Dorgali and Orosei and in the Urzulei - Oliena Supramonte (their Figs 2 and 6). Arragoni et al. (2016) model suggests (without any supporting data) also overthrust of Variscan basement above the Jurassic-Cretaceous successions (their Fig. 9).

\section{Critics to the model}

Insufficient attention is paid by Arragoni et al. (2016) to the stratigraphic complexity of the study area (documented in several papers, only partly cited in the text) and to the field evidence of stratigraphic continuity (Fig. 1), incompatible with the model proposed by these authors. Consequently, someone has to be wrong: all the authors that do not recognize regional-scale thrusts in the Mesozoic succession of Eastern Sardinia or those who suggest a Cenozoic thrust and fold belt affecting the same succession. This issue is not a simple question of possible different interpretations of a few outcrops, as the correct interpretation of these surfaces is critical for the reconstruction of the Cenozoic orogenic events in the Mediterranean area.

This discussion aims to (i) provide a constructive criticism to the stratigraphic framework and bedding-attitude data presented in this paper, (ii) highlight a number of inconsistencies between their model and the stratigraphic record of Eastern Sardinia Mesozoic carbonate platforms and (iii) demonstrate the stratigraphic nature of the supposed tectonic contacts that support Arragoni et al. (2016) model, and, as a consequence, (iv) the absence of any Alpine thrust and fold belt in Eastern Sardinia. 
The main points of criticism toward the data provided in support of Arragoni et al. (2016) model are as follows:

(i) The chrono- and lithostratigraphic framework of the study by Arragoni et al. (2016; their Fig. 3) is oversimplified and unsuitable to capture hiatus and stratigraphic repetitions which are usually associated with thrust contacts. The lithostratigraphic distinction used by Arragoni et al. (2016) among dolomite facies (Dorgali Fm.), thinto thick-bedded carbonates (Tului Fm.), and massive skeletal and locally biohermal limestone and carbonate breccias (Bardia Fm.) poorly captures the depositional architecture of eastern Sardinia Jurassic carbonate depositional systems (Dieni \& Massari, 1986; Jadoul et al. 2009, 2010). These are characterized by lateral facies and thickness changes with regional stratigraphic surfaces locally characterized by sedimentary erosional surfaces, typically when slope facies prograde on basinal successions, as documented by channelized breccia lenses at the toe of carbonate slopes (Jadoul et al., 2010). Furthermore, available biostratigraphic data indicate that the boundary between lithstragraphic units are strongly diachronous (e.g. Dieni \& Massari, 1986; Jadoul et al. 2009, 2010).

(ii) The lithostratigraphic framework of Arragoni et al. (2016) is locally incorrect. A few examples: the "West Sector" stratigraphy shows a stratigraphic contact between the Dorgali and Bardia formations marked by a long hiatus corresponding to the Oxfordian to Early Tithonian ( 13Ma). However, available geological literature indicate the presence of Oxfordian to Early Tithonian oolitic shoal and reefal facies of the Tului Fm. (Lanfranchi et al., 2011; Jadoul et al., 2009; 2010). The authors' statement that the Pedra Longa Formation is lateral equivalent with the Mt. Tului Fm. (at page 5) is incorrect and in disagreement with the biostratigraphic data of Jadoul et al. (2009, 2010) and Casellato et al., 2012.

(iii) Following the discussion at point (ii), Arragoni et al. (2016) geological map for the Urzulei Supramonte (their Fig. 2) is incorrect and what Arragoni et al. (2016) refer to as Mt. Bardia Formation belongs in most of this area to the underlying Mt. Tului Formation. Again, we suggest that the incorrect stratigraphic attribution of Arragoni et al. (2016) hampers a sound identification of stratigraphic vs tectonic contacts. 
(iv) The main supporting evidence for Arragoni et al. (2016) model is a simplified "statistical" dip-domains map integrated with rose diagrams (their Fig. 5). Potential pitfalls of this analysis are as follows:

- the presented dataset does not account for primary clinostratified depositional geometries (Fig. 1a) of carbonate depositional systems such as those documented in the Mt. Bardia Fm. (Lanfranchi et al., 2008, 2011; Jadoul et al., 2009, 2010);

- the authors ascribe all the present-day bedding attitude to compressional tectonism, without restoring this dataset to remove the effects of the younger strike-slip tectonism, which played a major role in defining the present-day structural architecture of the study area (Pasci, 1997; Pasci et al., 1998; Oggiano et al., 2009).

For example, increasing bed dips recorded along the western flank of the "Baunei Sincline" (their Figs 2 and 5) reflects the presence of prograding carbonate clinoforms and not only tectonic deformation. For example, Lanfranchi et al. (2008, 2011), clearly illustrate bedding changes related to clinostratification in a prograding platform above flat-lying basinal sediments. The Late Tithonian carbonate clinoforms of Nuraghe Punnacci (shown by Arragoni et al., 2016, in their Fig. 6D), display primary slope angles up to $15-20^{\circ}$, dipping to the east. Outcrops of clinostratified prograding carbonate deposits are also documented in the Genna Silana Valley and at Dorgali (Jadoul et al., 2009, 2010), suggesting that the reduced changes in bed attitude cannot be ascribed only to thrust tectonics. A meaningful interpretation of bedding attitudes (especially when dip differences are reduced) should definitely account for primary depositional geometries of carbonate units.

We suggest that the interpretation of bedding attitudes without any reference to the primary depositional geometry of carbonate bodies (i.e. clinostratified vs. flat-laying) and to the effects of post compressional strike-slip tectonic activity might be misleading in defining dip domains as proposed by Arragoni et al. (2016), and insufficient to support the proposed model.

(v) The layer-cake carbonate stratigraphy used in the Arragoni et al. (2016) balanced crosssection (page 11) does not reflect thickness and facies changes of the carbonate succession in eastern Sardinia. For example, dolomite facies (Dorgali Formation) are thicker in the Supramonte area (up to $200 \mathrm{~m}$ ) and then decrease outboard where the 
dolomite thickness is strongly reduced (few tens of metres). Conversely, the Mt. Bardia Fm. shows a maximum thickness of $\sim 500 \mathrm{~m}$ in the coastal area of the Orosei Gulf and at Mt. Tuttavista and then decreases toward the Supramonte area reflecting variations in the available accommodation space.

(vi) In their figures 6A and 6D, Arragoni et al. (2016) re-interpret well-documented stratigraphic contacts as thrust-flats, without providing convincing documentation. The flat surfaces of Arragoni et al. (2016) have been invariably placed on lithological boundaries and stratigraphic surfaces, where biostratigraphic data record a continuous stratigraphic evolution, with no evidence of stratigraphic separation due to the supposed tectonics. Only locally, close to the strike-slip faults described by Pasci (1997) and Pasci et al. (1998) gaps in the continuity of the stratigraphic succession are reported. Below it follows a brief comment to Arragoni et al. (2016) thrust-flat contacts:

- Their Figure 6A shows a supposed tectonic contact between the Dorgali and Bardia Formation. First of all, the attribution of the limestone succession to the Bardia Fm. is erroneous, and the limestone succession shown in this figure comprises oolitic shoal facies and coral patch reef overlain by peritidial cycles of the Tului Fm. and the Urzulei Fm. In addition, the stratigraphic succession of dolomite, shoal and reefal facies, and peritidal cycles characterise the entire Urzulei Supramonte and not only the alleged trust slice (Lanfranchi et al., 2008; Jadoul et al., 2009, 2010).

- Their Figure 6D illustrates another supposed tectonic contact at the base of the Mt. Bardia Formation. The outcrop shown in this picture and the entire southern part of the Orosei Coastal Massif, has been subject to extensive sedimentological, stratigraphic and biostratigraphic investigations (Jadoul et al., 2009, 2010; Lanfranchi et al., 2011). These analyses documented stratigraphic continuity between the Pedra Longa thin bedded facies and the overlying progradational facies of the Mt. Bardia F (Fig. 1, see also Fig. 10 of Jadoul et al., 2010). The stratigraphic setting of the Nuraghe Punnaci area is described in detail by Jadoul et al. (2010) in their Fig. 10, 14 and 18 and Jadoul et al. (2009) in their Fig. 10 and 11. These papers has been quoted by Arragoni et al. (2016), but it seems that a limited attention was paid to the stratigraphic data reported here, which do not support Arragoni et al. 
(2016) model. The hypothetical shear folds of Arragoni et al. (2016) (their Fig. 6D) are soft-sediment deformations and lens-shaped resedimented calcarenites and intraclasts rudstones related to progradation of the overlying Bardia shallow water platform (Fig. 1b, c).

The major tectonic feature in the Nuraghe Punnaci area is a regional strike-slip fault shown in Fig. 13 and 15 of Jadoul et al. (2010). Close to this fault, decimeter- to meterscale displacement can be locally observed at the base of the Mt. Bardia Fm., as typically occur in a multilayer consisting of massive and bedded carbonates. However these features could not support a displacement of tens of kms as suggested by Arragoni et al. (2016; their Fig. 2). The contact between Pedra Longa and Bardia Fm. is characterized by erosional truncations (Fig. 1b, c, d), with deposition of breccias and megabreccias (Jadoul et al, 2009; 2010) that can be seen also along the coast at Pedra Longa (Fig. 1e)

(vii) In their Fig. 9, Arragoni et al. (2016) propose a thrusting of Variscan basement above the Mesozoic carbonate succession at least in two structural levels, but in all the study area no outcrop evidence of this interpretation is present. The Variscan basement is uplifted with respect to the Mesozoic sedimentary succession only along strike slip faults (e.g. Pasci, 1997, Jadoul et al., 2008, their Fig. 13). Everywhere else, the contact between the sedimentary succession and the basement is a disconformity surface, locally associated with limited detachment, but never a thrust. The authors are seemingly aware that in the whole Orosei Gulf there is not any outcrop supporting a basement thrust over the carbonates. At page 13, they state that the thrust at Monte Oseli, which resulted in the Paleozoic basement overlying the Monte Bardia Formation is "nowadays hidden by the later strike-slip tectonic event". We wonder whether the basement-over-carbonates contact is (i) just an offspring of their model, or (ii) the authors own unpublished subsurface data supporting this scenario.

\section{Conclusions}

Arragoni et al. (2016) manuscript investigated the debated structural/geodynamic Cenozoic evolution of Eastern Sardinia. The study presents a tectonic model with plausible geometries and tectonic relationships. However, it is based on a dataset consisting of bedding attitude alone (in a succession characterized by clinostratified vs. originally horizontal bedding surfaces, a point not 
considered by Arragoni et al; 2016) and incorrect stratigraphic interpretations. The stratigraphic correctness is not a simple matter of precision, but it represents a major control on the existence of gaps or repetitions in the stratigraphic succession. The misinterpretation of the stratigraphic succession has major consequences on the correct interpretation of the tectonics affecting the Mesozoic succession of Eastern Sardinia (see the general consideration at point 7 of the Conclusions in Dieni et al., 2008). A major flaw of this study is that Arragoni et al. (2016) misinterpreted major stratigraphic contacts as tectonic surfaces, against geological evidence and published sedimentological and biostratigraphic data. There is no evidence of regional thrusts at the base of the Mt. Bardia Formation, which is instead a stratigraphic surface marked the progradation of shallow water limestones above bedded, basinal outer platform facies (Dieni \& Massari, 1986; Jadoul et al., 2008, 2009; 2010; Lanfranchi et al., 2008, 2011). The tectonic doubling of the stratigraphic succession and the shortening of several $\mathrm{km}$ proposed by Arragoni et al. (2016) are unrealistic and not supported by any type of field data, as indicated by sedimentological and stratigraphic evidence. No evidence of a Cenozoic fold and thrust belt with tens of $\mathrm{km}$ shortening and triplication of the Mesozoic sedimentary succession is present in Eastern Sardinia (in no places, for example, thrusts of Variscan basement above Mesozoic carbonates with several $\mathrm{km}$ of displacement can be observed).

It follows that (i) the balanced geological section of Arragoni is a pure geometric exercise missing the basic data needed to nurse the proposed model and, though being technically correct, it does not reflect the geology of eastern Sardinia, and (ii) the inferred Cenozoic geodynamic evolution of eastern Sardinia relies upon incorrect geological data. In conclusion, the data provided by Arragoni et al. (2016) do not supported the presence of an Alpine thrust and fold belt in eastern Sardinia and this paper may suggest to the geological community a misleading interpretation of the geodynamic evolution of the Alpine and Mediterranean area.

\section{Acknowledgments}

The data used are listed in the references, described in the text and in the figure. We would like to thank the reviewer Laurent Jolivet and the Editor for their useful comments that helped us in improving the original version of this contribution. 


\section{References}

Alvarez, W. (1972), Rotation of the Corsica-Sardinia Microplate, Nature, 235, 103-105, doi:10.1038/physci235103a0.

Arragoni, S., M. Maggi, P. Cianfarra, and F. Salvini (2016), The Cenozoic fold-and-thrust belt of Eastern Sardinia: Evidences from the integration of field data with numerically balanced geological cross section, Tectonics, 35, doi:10.1002/2015TC004004.

Casellato, C. E., F. Jadoul, \& A. Lanfranchi (2012), Calcareous nannofossil biostratigraphy of the S'Adde Limestone (Mt. Albo, Orosei Gulf): insights into the Middle-Late Jurassic Eastern Sardinia passive margin evolution. Rivista Italiana di Paleontologia e Stratigrafia (Research In Paleontology and Stratigraphy), 118(3), 439-460.

Casula, G., Cherchi, A., Montadert, L., Murru, M., \& Sarria, E. (2001). The Cenozoic graben system of Sardinia (Italy): geodynamic evolution from new seismic and field data. Marine and Petroleum Geology, 18, 863-888.

Carmignani, L., F. A. Decandia, L. Disperati, P. L. Fantozzi, A. Lazzarotto, D. Liotta, and G. Oggiano (1995), Relationship between the Tertiary structural evolution of the Sardinia-Corsica-Provençal Domain and the Northern Apennines, Terra Nova, 7, 128-137, doi:10.1111/j.13653121.1995.tb00681.x.

Dieni, I. and F. Massari (1985), Mesozoic of Eastern Sardinia, In: 19th European Micropaleontological Colloquium. Sardinia October 1-10, 1985. Micropaleontological Researches in Sardinia. Guidebook (Ed. A. Cherchi), pp. 66-77. Editar, Cagliari.

Dieni, I., F. Massari and J. Médus (2008), Age, depositional environment and stratigraphic value of the Cuccuru 'e Flores Conglomerate: insight into the Palaeogene to Early Miocene geodynamic evolution of Sardinia, Bull. Soc. Géol. Fr., 179, 51-72.

Jadoul F., A. Lanfranchi, F. Berra, E. Erba and C. Casellato (2010), I sistemi carbonatici giurassici della Sardegna orientale Prima parte della Guida della escursione E5 pre-congresso Soc.Geol.Ital. 84 Congresso di Sassari 15-17 settembre 2008. Parte 1 della guida 1-34. Guide field trip della Soc.Geol It. Rivista online. DOI 10.3301/GFT.2010.02

Jadoul, F., A. Lanfranchi. and F. Berra (2009), Evolution of Late Jurassic to Berriasian carbonate platforms of eastern Sardinia, In: Field Trip Guide Book, Pre-Conference Field Trip FT3, 27th IAS Meeting of Sedimentology, Alghero, September 20-23, 2009 (Eds V. Pascucci and S. Andreucci), pp. 51-72. Sassari, Italy.

Lanfranchi, A., F. Berra, F. Jadoul (2011), Compositional changes in sigmoidal carbonate clinoforms (Late Tithonian, eastern Sardinia, Italy): insights from quantitative microfacies analyses, Sedimentology, 58, 2039-2060.

Oggiano, G., A. Funedda, L. Carmignani, and S. Pasci (2009), The Sardinia-Corsica microplate and its role in the Northern Apennine geodynamics: New insights from the Tertiary intraplate strike-slip tectonics of Sardinia, Boll. Soc. Geol. Ital., 128(2), 527-539, doi:10.3301/IJG.2009.128.2.527.

Pasci S. (1997), Tertiary transcurrent tectonics of North-Central Sardinia, Bull. Soc. Geol. Fr., 168, 301312.

Pasci, S., G. Oggiano, and A. Funedda (1998), Rapporti tra tettonica e sedimentazione lungo le fasce trascorrenti oligo-aquitaniane della Sardegna NE, Boll. Soc. Geol. Ital., 117, 443-453. 


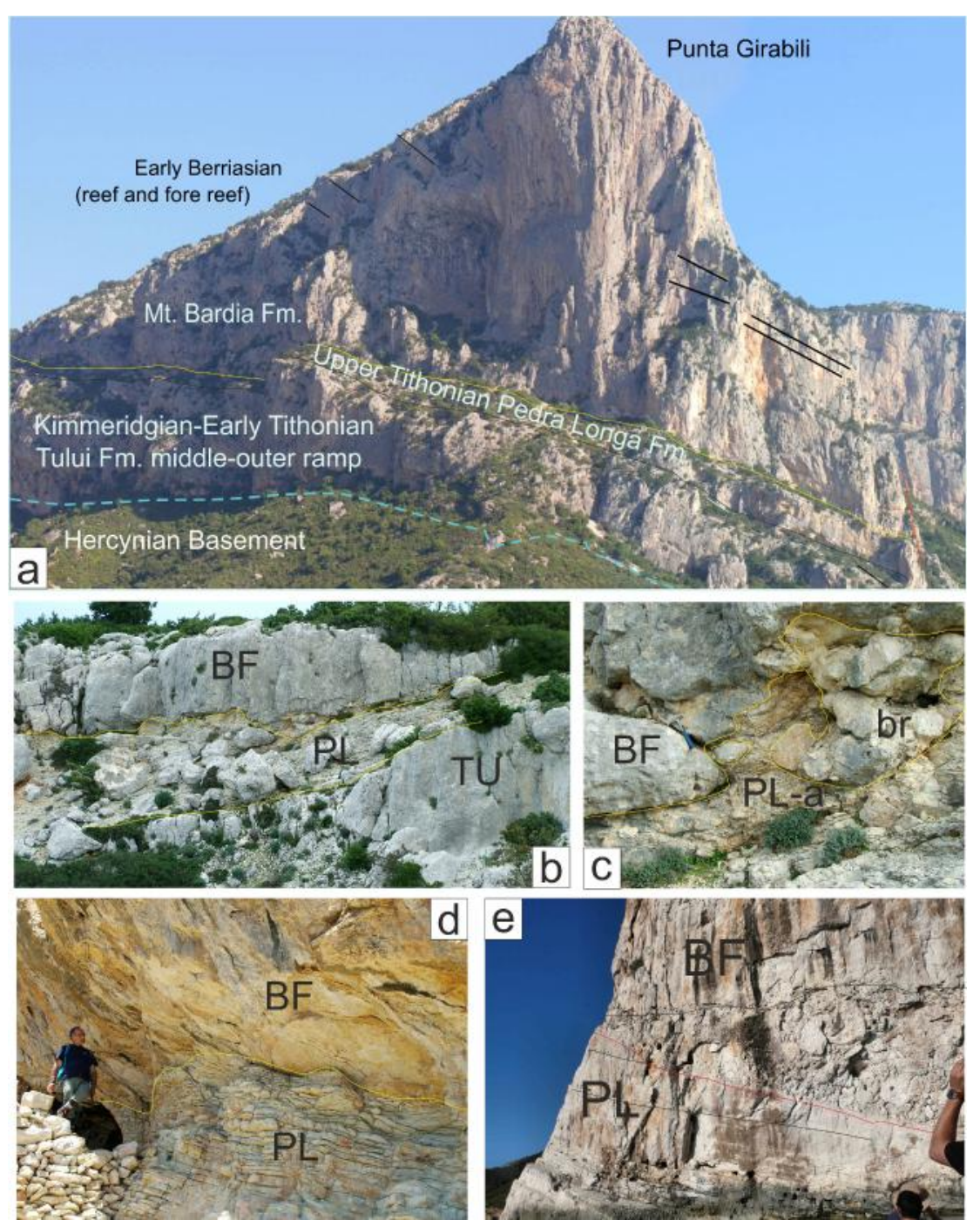

Figure 1. - Geological setting and lithological boundaries in the Upper Jurassic-Lower Cretaceous carbonate succession of the Baunei area. a) panoramic view of the Bardia Fm. prograding from west (left) to east (right) on the basinal facies of the Pedra Longa Fm., deposited after the drowning of the shallow-water facies of the Tului Formation; b) contact between Bardia (BF), Pedra Longa (PL) and Tului (TU) Formations at the Nuraghe Punnaci outcrop: note the sharp contact between Tului and Pedra Longa Fm. (marking the downing of the Tului Fm.) and the irregular basal surface of the prograding slope facies of the Baunei Fm.; c) detail of the contact between Pedra Longa and Bardia Fms: note the irregular base of the Bardia Formation (BF), the presence of breccia lenses and isolated clasts (br) and the soft-sediment deformation (pre-litification) of the Pedra Longa Formation (PL-a) due to the rapid deposition of the prograding facies of the Bardia Fm. No evidence of any regional tectonic surface can be observed at the contact between Bardia and Pedra Longa Fms; d) view of the stratigraphic contact between the thinbedded fine-grained limestone of the Pedra Longa Fm. (PL) and the overlying Bardia Fm. (BF), here consisting of massive resedimented limestone (Pietra Litografica Quarry, east of Baunei, along the road from Baunei to Pedra Longa). Note the soft-sediment deformation of the bedded limestone and the slightly erosional base at the toe of the prograding M. Bardia Fm.; e) channel (red line for base) carved in the basinal sediments of Pedra Longa Formation filled by coarse breccia at the base of the prograding slope facies of the Bardia Formation, along the coast at Pedra Longa. This stratigraphic contact between Monte Bardia (BF) and Pedra Longa (PL) Fms. is exactly the place where Arragoni et al. (2016) place in their model the Supramonte di Baunei/Serra Ovara thrust, with a suggested throw of several hundreds of meters. 